\title{
Özel Öğrenci Etüt Eğitim Merkezi Rehberlik ve Denetim Rehberinin Yasal Belgeler ve Alanyazın Temelinde İncelenmesi
}

\author{
Dr. Aysun AKÇAY GÜNGÖR \\ Milli Eğitim Bakanlığı-Türkiye \\ aakcay86@gmail.com
}

\begin{abstract}
Özet:
Bu araştırmanın amacı Özel Öğrenci Etüt Eğitim Merkezleri Rehberlik ve Denetim Rehberini yasal belgeler ve alanyazın temelinde incelemektir. Araştırmada nitel araştırma yöntemlerinden doküman inceleme yöntemi kullanılmıştır. Doküman incelemesi, araştırılması hedeflenen olgu veya olgular hakkında bilgi içeren yazılı materyallerin analizini kapsar. Elde edilen veriler, içerik analizine tabi tutulmuştur. Araştırma bulgularına göre denetim rehberinin yasal belgelerle genel anlamda tutarlı olduğu görülmüştür. Bununla birlikte rehberde yasal dayanağa eksik, fazla ya da hatalı gönderme yapıldığı, mülga maddelere gönderme yapıldığı, rehberde yasal boşlukların bulunduğu ve yasal dayanağa internetten ulaşamama gibi tutarsılıkların olduğu tespit edilmiştir. Rehber alanyazın temelli incelendiğinde, rehberin alanyazınla çoğunlukla tutarlı olduğu görülmekle birlikte rehber oluşturulurken alanyazındaki herhangi bir araştırmaya, kitaba, çalışmaya atıf yapılmadığı, alanyazından elde edilen bulgulara rehberde yer verilmediği bulgularına ulaşılmıştır. Özel öğrenci etüt eğitim merkezi denetim rehberinin alandan uzman akademisyenler ve hukukçuların da desteğiyle yeni yasal belgeler ve alanyazın temele alınarak güncellenmesi, rehberde yer alan tüm yasal belgelerin ulaşılabilir bir ortamda toplanması önerilebilir.
\end{abstract}

Keywords: Denetim Rehberi, Özel Öğrenci, Etüt Eğitim Merkezi, Yasal Belgeler.

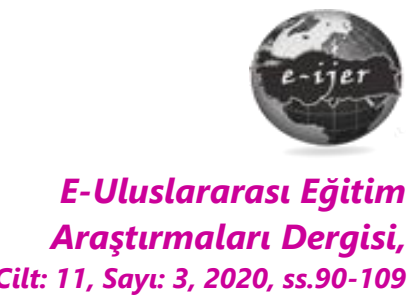

DOI: 10.19160/ijer.820632

Gönderim : 03.11.2020 Kabul : 06.12.2020

\section{Önerilen Atıf}

Güngör, A., A. (2020). Eğitim Özel Öğrenci Etüt Eğitim Merkezi Rehberlik ve Denetim Rehberinin Yasal Belgeler ve Alanyazın Temelinde İncelenmesi, E-Uluslararası Eğitim Araştırmaları Dergisi, Cilt: 11, Sayı: 3, 2020, ss. 90-109, DOI: 10.19160/ijer.820632 


\section{Giriş}

Eğitim olgusunun örgütlü bir hale dönüşmesi, insanlık tarihi ile birlikte ele alındığında oldukça uzun bir zaman gerektirmiştir. Toplumlar geliştikçe meslek yaşamında uzmanlaşmaya duyulan ihtiyaç arttığından, toplumun eğitim amaçlarını gerçekleştirmek üzere kurulmuş insan ve teknolojiden oluşan eğitim örgütlerine duyulan gereksinim de artmıştır. Vatandaşlık görevinin gerektirdiği bilgi, beceri ve değerlerin herkese aynı şekilde verilmesi, herkesin ortak bir eğitim sürecinden geçirilmesi ile olanaklı olabileceğinden, karmaşıklaşan toplum, eğitimi örgütlemek zorunda kalmıştır (Toprakçı, 2013). Eğitsel faaliyetler, eğitim örgütleri vasıtasıyla örgütlenerek bir taraftan tek çatı altında toplanmaya çalışıırken; bir taraftan da artan insan ihtiyaçlarına cevap verebilmek adına çeşitli dallara ayrılarak daha çok uzmanlık gerektiren bir yapıya dönüşmüştür. Çeşitlenen eğitim örgütlerinden daha nitelikli eğitim vermeleri, saydam ve hesap verir olmalarına ilişkin beklenti arttığından (Thakral, 2015), eğitim sisteminin her türü ve kademesinde eğitim denetimin önemi artmıştır (Özen ve Hendekçi, 2016).

Denetim kavramı tarihsel süreç içerisinde farklı açılardan ele alınmış ve farklı şekillerde tanımlanmıştır. Yönetimin tarihsel gelişimine paralel olarak denetim de 20. yüzyılın başlarında bilimsel yönetim anlayışıyla kontrol işlevini üstlenerek öğretimin etkililiğini arttırması amaçlamıştır (Kesik ve Aksu, 2015). Örgütsel eylemlerin kabul edilen amaçlar doğrultusunda, saptanan ilke ve kurallara uygun olup olmadığının anlaşılması sürecine denetim denir. Bu nedenle örgütlerin amaçlarına ulaşabilmeleri için denetim işlevinin yerine getirilmesinin hayati önem taşıdığı söylenebilir (Aksu, İra, Çek, 2012). Örgütsel ve yönetimsel bir zorunluluk olarak nitelendirilen denetim ile örgütün amaçlarını gerçekleştirme derecesinin saptanması, mevcut durumu iyileştirmek üzere gerekli önlemlerin alınması ve böylelikle sürecin iyileştirilmesi ve geliştirilmesi amaçlanmaktadır (Akkaş, Aksu, Yurttaş ve Yıldırım, 2019). Kısacası denetimin temel amacı, örgütün amaçlarının gerçekleştirilme derecesini saptamak, daha iyi sonuç alabilmek için gerekli önlemleri almak (Aydın, 2014) ve süreci kamu yararı adına geliştirmektedir (Bursalıoğlu, 2015).

Denetimin, değerlendirme işlevinin yönetim sürecinin bir öğesi olarak ilk kamu kuruluşlarının örgütlendirildiği dönemle birlikte başladığı söylenebilir (Öz, 2003). Türk eğitim sisteminde de kurumların amaçlarını gerçekleştirip gerçekleştirmediğini ya da ne derece gerçekleştirdiklerini belirlemek için yapılan değerlendirme, denetim yoluyla yapılır.

Denetim, eğitim sisteminin bir alt sistemidir (Özen ve Hendekçi, 2016) ve Argyris (1993)'e göre denetim ve destek, eğitimin kalitesinin geliştirilmesinin vazgeçilmezleridir. Eğitim sisteminde yaşanan her tür değişim, denetim sistemine de yansır (Oktar, 2010). Denetim sürecinde etik dışı davranışların fark edilerek erdemli ve duyarlı olma bilinciyle ortaya çıkarılması sonraki süreçlerin de daha iyi işlemesi açısından etkili olabilir (Aksu, Yılmaz ve Orçan, 2016). Denetim uygulamaları geliştirici, yapıcı ve tarafsız olarak yürütüldüğünde eğitimin niteliği de artmaktadır. Geribildirimin olduğu bir sistem gelişmeye de açık bir sistemdir. Bu da denetim çalışmalarının yapılmasını bir zorunluluk haline getirmektedir. Denetimin örgüt açısından zorunlu oluşu, örgütün öz varlığını sürdürmeye kararlı oluşunun doğal bir sonucudur. Eğitim denetimi, eğitimde gerçekleştirilen eylemlerin; mevcut yasal işleyişe, belirlenen amaca, hazırlanan plana, eldeki madde ve insan kaynaklarına uygun olup olmadığını kontrol etme sürecidir (Toprakçı, Çakırer, Bilbay, Bagcivan ve Bayraktutan, 2010). Eğitim denetimi, yapılan 
uygulamaların geri bildirimlerini alma, mevcut durumu ortaya koyabilme, gelişim açısından gerekli düzenlemeleri ve yönlendirmeleri yapabilme, uygun ortamların oluşturulmasına katkı sağlayabilme açılarından eğitim yönetiminde büyük önem taşımaktadır. Bu bakımdan, her ulus, eğitim sisteminin niteliklerine göre, eğitim denetiminde etkililiği sağlayabilme açısından, çeşitli uygulamaları hayata geçirmektedir (Demirtaş ve Ersözlü, 2007; Özmen ve Yasan, 2007; Erdem, 2008; Yılmaz, 2009).

Üniter devlet yapısına sahip olan Türkiye, eğitim ve öğretimin birlik ve bütünlüğünü sağlama görev ve sorumluluğu ile okul/kurum denetimini; Türkiye Cumhuriyeti anayasanın 42. Maddesi gereği "Atatürk ilkeleri doğrultusunda, çağdaş bilim ve eğitim esaslarına göre, devletin gözetim ve denetimi altında yapılır" Ifadesinden hareketle, eğitim öğretim faaliyetlerini Millî Eğitim Bakanlığının gözetim ve denetiminde yapmaktadır. Bu görev, 652 sayılı Kanun Hükmünde Kararname ile Milli Eğitim Bakanlığı Rehberlik ve Denetim Başkanlığının uhdesindedir (MEB, 2016). Ayrıca, 3/3/1924 tarih ve 430 sayılı Tevhidi Tedrisat Kanunu, 14/6/1973 yılında kabul edilen ve hala yürürlükte olan 1739 sayılı Milli Eğitim Temel Kanunu, 222 sayılı İlköğretim ve Eğitim Kanunu, 30/4/1992 tarih ve 3797 sayılı Milli Eğitim Bakanlığı Teşkilat ve Görevleri Hakkında Kanun ve Milli Eğitim Bakanlığına yönelik özel Kanunlar, yönetmelikler ve yönergeler ile Türkiye'de kurum/okul denetiminden Milli Eğitim Bakanlığı tarafından 3797 sayılı Milli Eğitim Bakanlığı Teşkilat ve Görevleri Hakkında Kanunda da yer alan Teftiş Kurulu Başkanlığı sorumludur (Erdem ve Sarpkaya, 2011).

Araştırma kapsamında incelenen özel öğrenci etüt eğitim merkezlerinin de içinde bulunduğu özel öğretim kurumları, Bakanlık maarif müfettişleri/Bakanlık maarif müfettiş yardımcıları veya il millî eğitim müdürlüğünce görevlendirilen şube müdürü ile diğer denetim yetkisi bulunanlarca denetlenir. Bu kurumların denetimlerinde, bakanlıkça hazırlanan modüller ile diğer elektronik araç ve gereçlerden de yararlanılabilir (MEB,2016). Denetçilerin denetim görevini yerine getirirken faydalanmaları amacıyla Teftiş Kurulu Başkanlığı tarafından hazırlanan Rehberlik ve Denetim Rehberleri bulunmaktadır. Bu rehberler, Milli Eğitim Bakanlığı'nı ilgilendiren konularda bakanlık personeline, bakanlığa bağlı okul ve kurumlarına, özel öğretim kurumlarına, gerçek ve tüzel kişiler ile gönüllü kuruluşlara uygulamalarında yol göstermek; hizmetlerin kontrol ve denetimini ilgili birimlerle iş birliği içinde yapmak; süreç ve sonuçlarını mevzuata, belirlenmiş amaç ve hedeflere, performans ölçütlerine ve kalite standartlarına göre analiz ederek sonuçları rapor hâlinde ilgili birimlere ve kişilere iletmek, eğitim-öğretimin kalitesini arttırmak, Maarif Müfettişleri Başkanlıkları arasında uygulama birliği ve standartlaşmayı sağlamayı amaçlamaktadır (MEB, 2016).

Özel öğrenci etüt merkezleri 24/06/2011 tarih ve 27974 sayılı "Özel Öğrenci Etüt Eğitim Merkezleri Yönetmeliği" ne göre, "Öğrencilerin, derslerine çalışmalarına, ödev ve projelerini hazırlamalarına yardımcı olan, ilgi, istek ve yetenekleri doğrultusunda çeşitli faaliyetlerin yürütüldüğü özel öğretim kurumları" şeklinde tanımlanmaktadır. Özel öğrenci etüt eğitim merkezlerinin amacl, Türk millî eğitiminin genel amaçlarına ve temel ilkelerine uygun olarak ilköğretim okullarına devam eden öğrencilerin, öğretmen gözetiminde derslerine çalışmalarına ve yönetmelikte belirtilen alanlarda etkinliklerde bulunmalarına yardımcı olmaktır. Özel öğrenci etüt merkezlerinde etüdün yanı sıra programı valilikçe uygun görülen; halk oyunları ve çeşitli spor dalları, tiyatro, müzik, resim, heykel, oymacılık ve seramikçilik alanları, fotoğraf, projeksiyon ve sinema, 
koleksiyonculuk, sosyal ve fen bilimleri alanlarında inceleme ve araştırma, güzel konuşma ve yazma, kitap okuma gibi etkinliklerin birkaçı veya tamamı uygun yaş ve seviye grupları oluşturularak yapılır. Öğrencilerin gezi, sinema, tiyatro, konferans, konser ve benzeri etkinliklerden yararlanmaları sağlanabilir. Bu etkinlikler, ilgili mevzuat hükümlerine göre yürütülür. Öğrenci etüt eğitim merkezlerinde; özel dershane etkinlikleri kapsamında bulunan ve öğrencilerin bir üst öğrenime hazırlanması veya test uygulaması gibi etkinlikler yapılamaz. Bu etkinlikleri yapan kurumlar hakkında 5580 sayılı Özel Öğretim Kurumları Kanununun 7. maddesi hükümleri uygulanır (Resmi Gazete, 2011). Amacı ve kapsamı incelendiğinde özel öğrenci etüt merkezlerinin çok geniş bir alanda, geniş bir yaş aralığına eğitim veriyor oluşu bu kurumların denetlenmesinin ne kadar güç ve önemli olduğunu ortaya koymaktadır.

Bu araştırmada Özel Öğrenci Etüt Eğitim Merkezleri Rehberlik ve Denetim Rehberinin yasal belgeler ve alanyazın temelinde incelemek amaçlanmaktadır.

\section{YÖNTEM}

Bu bölümde araştırmanın modeli, verilerin toplanma süreci ve analizi hakkında bilgi verilmiştir.

Araştırmanın modeli: Araştırma özel öğrenci etüt eğitim merkezlerinin rehberlik ve denetim rehberini incelemeye yönelik bir araştırma olduğundan nitel araştırma deseninde, doküman inceleme yöntemiyle tasarlanmıştır. Doküman inceleme, hem basılı hem de elektronik materyalleri incelemek veya değerlendirmek için yapılan sistematik bir işlemdir. Diğer araştırma yöntemlerinde olduğu gibi doküman analizi yöntemi de, anlam çıkarmak, anlayış kazanmak ve ampirik bilgi geliştirmek için verilerin incelenmesi ve yorumlanmasını gerektirir. Doküman analizinde analitik işlem süreci, dokümanlarda yer alan verilerin bulunmasını, seçilmesini, değerlendirilmesini (anlamlandırılmasını) ve sentezlenmesini içermektedir (Bowen, 2009). Araştırma kapsamında incelenen MEB Teftiş Kurulu Başkanlığı tarafından hazırlanan Rehberlik ve Denetim rehberleri, teftiş yapanlar için bir kılavuz niteliği taşımakla beraber denetimde uygulama birliği sağlamak amacıyla kullanılan kamu belgeleridir. 2016 yılında yayınlanan, Milli Eğitim Bakanlığı'na bağlı olan ve MEB Teftiş Kurulunca denetlenen 16 farklı kuruma ait olan ve elektronik ortamdan ulaşılan bu belgelerden "Özel öğrenci etüt eğitim merkezlerine ait Rehberlik ve Denetim Rehberi", araştırma kapsamında doküman analizi tekniği aşamalarına uygun olarak analiz edilmiştir. Belgeye Milli Eğitim Bakanlığı Teftiş Kurulu Başkanlığı'nın resmi sitesinden 20.05.2020 tarihinde ulaşılımıştır.

Verilerin Toplanması ve Analizi: $\mathrm{Bu}$ araştırma doküman inceleme yöntemiyle yürütülmüştür. Doküman inceleme yaparken izlenebilecek bir dizi aşama vardır. Her araştırmacı bu aşamaları araştırma probleminin niteliğine, doküman incelemesi sonucu elde etmeyi hedeflediği veriye veya dokümanları ne kadar kapsamlı ve derinlemesine incelemek istediğine bağlı olarak yeniden yorumlayabilir. Doküman incelemesi belli başlı beş aşamada yapılabilir (Forster, 1994): Dokümanlara ulaşma, Orijinalliğini kontrol etme, Dokümanları anlama, Veriyi analiz etme, Veriyi kullanma aşamalarıdır.

İlk aşama olan dokümanlara ulaşma aşamasında, Milli Eğitim Bakanlığı Teftiş Kurulu resmi sitesinden "Özel öğrenci etüt eğitim merkezleri rehberlik ve denetim 
rehberi" ne ulaşılmıştır. Bu rehberde bahsi geçen kanun, yönetmelik, yönerge, genelge v.b tüm yasal kaynaklara da yine resmi gazetelerde yayınlanmış haliyle ulaşılmış ve tüm bu belgelerin orijinalliği başka yasal kaynaklarla internet ortamında karşılaştırılarak teyit edilmiştir. Üçüncü aşama olan dokümanları anlama basamağında araştırma kapsamına giren tüm yasal belgeler ayrıntılı olarak incelenmiş; belgelerde yer alan hukuksal ifadelerin ne anlatmak istediğini tam anlamıyla kavrayabilmek için ve analizi doğru yapabilmek adına bir avukattan yardım alınmıştır. Ayrıca eğitim yönetimi alanında uzman, doktorasını bu alanda tamamlamış altı akademisyenin de denetim rehberini okuyup incelemesi, yorumlaması, eksik ya da hatalı gördüğü yerleri belirtmesi istenmiştir.

Veriyi analiz etme aşamasında, araştırma kapsamında incelenen denetim rehberi rehberde yer alan dört ana başlık temelinde incelenmiştir. Bunlar: 1) Amaç, kapsam, dayanak; 2) Rehberlik ve denetim ilkeleri, 3) Rehberlik ve denetim esasları ve 4) Rehberlik ve denetim raporlama standartlarıdır. Bu temel başlıkların altında yer alan maddeler tek tek incelenmiş, ilgili olduğu yasal dayanaklarla karşılaştırılarak analiz edilmiştir. Elde edilen veriler, içerik analizi ile çözümlenmiştir. İçerik analizinde temel amaç, toplanan verileri açıklayabilecek kavramalara ve ilişkilere ulaşmaktır. Dokümanlar analiz edilirken "dokümanları anlama" basamağında özetlenen ve yorumlanan veriler, içerik analizinde daha derin bir işleme tabi tutulur. İçerik analizinde temelde yapılan işlem verilerin kodlanması, temaların bulunması, kodların ve temaların düzenlenmesi, bulguların tanımlanması ve bunları okuyucunun anlayabileceği bir biçimde organize ederek yorumlamaktır (Yıldırım ve Şimşek, 2013). Falkingham ve Reeves (1998) de içerik analizinin, yayın yığınlarının değerlendirilmesi için kullanılan yeni bir yöntem olduğunu ifade etmiştir. Bundan dolayı verilerin analizi aşamasında öncelikle söz konusu rehber ve gönderme yaptığı yasal belgeler incelenmiş; alanyazın ile ilişkisinin analizi işlemi için ise, araştırmacılar rehberi çevrim içi ortam ile gerçek ve sanal kütüphanelerin yardımcı araçları ile "alanyazınsal zihin çerçeveleri" sınırlığında aşkınlık seviyesine gelinceye kadar okuyarak kod, kategori ve temalara ulaşmışlardır. Alanyazın ile ilişkisi ise çalışmayı yapanların bulunan kaynaklar ile "alanyazınsal zihin çerçeveleri" sınırlılığında gerçekleştirilmiştir. Bu süreçte çelişkiye düşülen durumlarda kaynaklara, meslektaş teyidine, uzman görüşüne başvurulmuştur. Buna göre özel öğrenci etüt eğitim merkezleri denetim rehberinin yasa ve alanyazın ile olan ilişkisi temalar olarak biçimlenirken, yasal belgeler ve alanyazın ile ilişkisinde tutarlıık ve tutarsızlık şeklinde kategorilere ayrılmıştır. Bunlar,"Denetim Rehberinin Yasal Belgelerle Tutarlıı̆ı", "Denetim Rehberinin Yasal Belgelerle Tutarsılı̆ı", "Denetim Rehberinin Alanyazınla Tutarlıı̆ı" ve "Denetim Rehberinin Alanyazınla Tutarsızlığı" olarak ortaya çıkmıştır. Araştırmanın son aşaması olan veriyi kullanma aşamasında belirlenen temalara uygun şeklide denetim rehberinden alıntılama yapılarak analiz yorumlarla desteklenerek tamamlanmıştır. Yapılan içerik analizi örneği Tablo 1'de verilmektedir.

Doküman incelemesinin aşamalarından olan verinin analiz edilmesi basamağının daha anlaşılabilir olabilmesi için araştırma kapsamında incelenen denetim rehberinin alanyazın ve yasal belgelerle tutarlılığı ve tutarsızlığına bakılmış, elde edilen Tema, Kategori ve Kodlara ait örnek ifadeler Tablo 1'de gösterilmiştir. 
Tablo 1: Özel Öğrenci Etüt Eğitim Merkezleri Rehberlik ve Denetim Rehberinin" yasal belgeler ile alanyazın temelinde analizi sonucu belirlenen temalar ve bu temalarla ilişkin ifadeler

\begin{tabular}{|c|c|c|c|}
\hline Tema & Kategori & Kodlar & Temayla ilişkili ifadeler \& Gönderme yapılan yasal belge/ ilgili madde \\
\hline \multirow{4}{*}{ 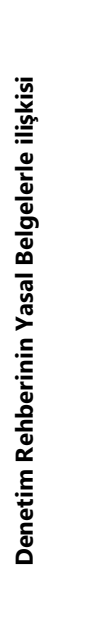 } & \multirow{2}{*}{ 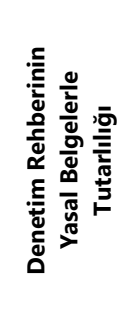 } & 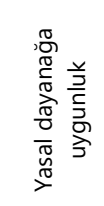 & $\begin{array}{l}\text { Rehberde: } \\
\text { "Ders araç-gerecinin kurumun amaçları için yeterli düzeyde olması (Özel Öğretim Kurumları } \\
\text { Kanunu Md.3)" } \\
\text { Yasal belgedeki karşılığı: } \\
\text { MADDE } 3 \text { - a) Ders araç-gerecinin kurumun amaç ve ihtiyaçları için yeterli olduğunun bir rapor } \\
\text { ile tespit edilmesi. }\end{array}$ \\
\hline & & \multicolumn{2}{|c|}{$\begin{array}{l}\text { "Ders araç-gerecinin kurumun amaçları için yeterli düzeyde olması " İfadesinin Özel Öğretim Kurumları } \\
\text { Kanunu madde 3'e gönderme yaptığı görülmektedir. İlgili kanunun a bendi incelendiğinde rehberdeki } \\
\text { ifadenin yasal dayanakla doğrudan ilişkili olduğu tespit edildiğinden bu kod tercih edilmiştir. }\end{array}$} \\
\hline & \multirow{2}{*}{ 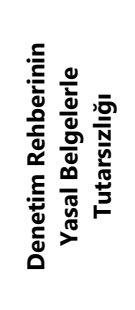 } & 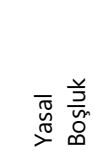 & $\begin{array}{l}\text { Rehberde: } \\
\text { "Panolara asılan resim, tablo, harita ve diğer dokümanların eğitim amaçlı olması." } \\
\text { Yasal belgedeki karşılığı: } \\
\text { Bu ifadenin gönderme yaptığı herhangi bir yasal dayanağa rehberde yer verilmemiştir. }\end{array}$ \\
\hline & & \multicolumn{2}{|c|}{$\begin{array}{l}\text { Rehberdeki "Panolara asılan resim, tablo, harita ve diğer dokümanların eğitim amaçlı olması." İfadesinin } \\
\text { karşısında herhangi bir yasal dayanak bulunmaması denetim rehberinde gerek denetimi yapan gerek } \\
\text { denetlenen kişi açısından muallaklık oluşturduğu için ve bahsi geçen ifadenin yasal bir karşılığı bulunmadığı } \\
\text { için bu kod tercih edilmiştir. }\end{array}$} \\
\hline \multirow[t]{4}{*}{ 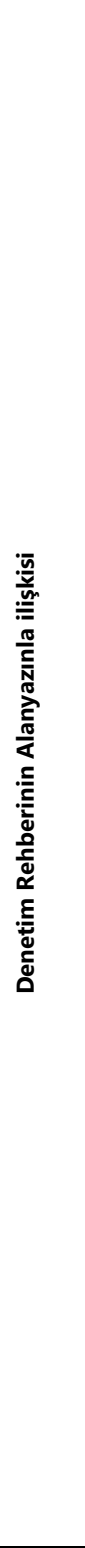 } & \multirow[t]{2}{*}{ 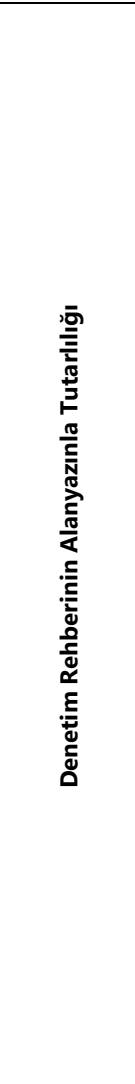 } & 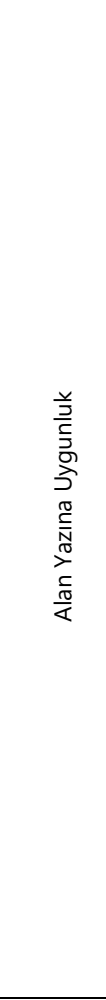 & $\begin{array}{l}\text { Rehberde: } \\
\text { Rehberlik ve denetimde aşağıdaki ilkeler gözetilir: } \\
\text { - Bireysel ve kurumsal farklııılar ile çevresel faktörleri dikkate almak, } \\
\text { - Yol gösterici ve önleyici rehberliği öne çıkarmak, düzeltmeyi, iyileştirmeyi ve geliştirmeyi esas } \\
\text { almak, } \\
\text { - İyi uygulama örneklerini yaygınlaştırmak, } \\
\text { - Usulsüzlük ve yolsuzlukları önleme yönelimli olmak, } \\
\text { - Açıklık, şeffaflık, eşitlik, demokratiklik, bağımsızlık, bütünlük, güvenilirlik ve tarafsızlığı esas } \\
\text { almak, } \\
\text { - İşbirliği ve katııımı öngörmek, } \\
\text { - Başarıyı öne çıkarmak, özendirmek, teşvik etmek ve ödüllendirmek, } \\
\text { - Personelin mesleki yeterliğini geliştirmek, } \\
\text { - Objektif olmak, } \\
\text { - Gelecek yönelimli olmak, } \\
\text { - Etkililik, ekonomiklik ve verimlilik esaslarını dikkate almak, } \\
\text { - Millî birlik ve bütünlüğümüzün temel unsurlarından biri olan Türkçenin doğru kullanılması } \\
\text { hususunda gerekli duyarlılığı göstermek, } \\
\text { - Kurumlarda rehberlik ve denetim faaliyetlerini birlikte yürütmek. } \\
\text { Alanyazında: } \\
\text { Rehberlik ve denetim ilkeleri şunlardır (Gökçe, 1994): } \\
\text { a. Denetimde bireysel farklılıklar göz önünde bulundurulur. } \\
\text { b. Denetim, başlayıp biten değil sürekliliği olan bir eylemdir. } \\
\text { c. Denetim, nesnel bulgulara ve bilimsel esaslara dayalıdır. } \\
\text { d. Denetim, iyi insan ilişkileri temeline dayalıdır. } \\
\text { e. Denetimle ilgili veriler ve denetim sonuçları denetlenenlerce açık olarak bildirilir. } \\
\text { e. Denetim, demokratik katılımı, katılanların işbirliğini ve eşgüdümünü esas alır. } \\
\text { f. Denetimde öğrenci, okul ve çevre koşulları dikkate alınır. } \\
\text { g. Denetim, eğitim etkinliklerinin tümünü içerir. } \\
\text { h. Denetim, önceden belirlenen amaçlara göre yapılır. } \\
\text { ı. Denetim eylemleri arasında tutarlıı vardır. } \\
\text { i. Denetim belli bir plana göre yürütülür. }\end{array}$ \\
\hline & & \multicolumn{2}{|c|}{$\begin{array}{l}\text { Rehberde yer alan rehberlik ve denetim ilkeleri ile alanyazında belirtilen ilkeler uyuştuğu için bu kod uygun } \\
\text { görülmüştür. }\end{array}$} \\
\hline & \multirow{2}{*}{ 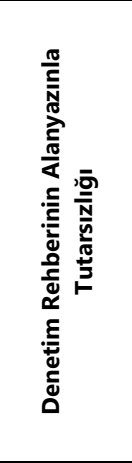 } & 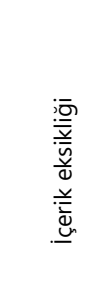 & $\begin{array}{l}\text { Rehberde: } \\
\text { Eğitim-öğretim ortamlarında sorunlar tespit edilirken; mevzuat, üst politika belgelerinde (Kalkınma } \\
\text { Planı, Hükümet Programı, Millî Eğitim Bakanlığı Stratejik Planı) eğitim ile ilgili ortaya konulmuş } \\
\text { amaç ve hedefler göz önünde bulundurulur. } \\
\text { Alanyazında: } \\
\text { Örgüt yapısının anlaşılması (Bursalıoğlu, 2015), örgüt kültürünün iyi tanınması, problemin iyi } \\
\text { analiz edilmesi (Şişman, 2011), okul içi ve dısı dengelerin gözetilmesi (Glatter ve Kydd, 2003) } \\
\text { eğitim ortamlarındaki sorunların tespiti ve çözümü aşamasında oldukça önemlidir. }\end{array}$ \\
\hline & & \multicolumn{2}{|r|}{$\begin{array}{l}\text { Rehberde eğitim-öğretim ortamlarındaki sorunların çözümünde sadece yasal dayanaklardan bahsedilmesi; } \\
\text { eğitim ortamının kendi iç dinamiklerinin bu kapsam çerçevesinde dile getirilmeyişi ve bu durumun } \\
\text { alanyazında karşıı̆ına bakıldığında ifadenin eksik kalmasından dolayı bu ifade söz konusu kodla } \\
\text { ilişkilendirilmiştir. }\end{array}$} \\
\hline
\end{tabular}


Denetim rehberinde yer alan ifadeler incelenirken bazı ifadelerin birden fazla kodla ilişkili olduğu saptanmıştır. Birden fazla kodla ilişkisi olan ifadeler ilişkili olduğu tüm kodların altında ayrı ayrı değerlendirilerek ilgili kategorilerdeki frekans değerlerine dahil edilmiştir. Örneğin rehberdeki "Yönetim Faaliyetleri" ana başlığının altında yer alan "Denetim, İzleme ve Değerlendirme" alt başlığındaki "Kantinlerin denetimi ve hijyen kurallarına uyulması, uyuşturucu kullanımı ve bağımlılık ile mücadele (Milli Eğitim Bakanlığı "Okul Kantinlerinde Satılacak Gıdalar ve Eğitim Kurumlarındaki Gıda İşletmelerinin Hijyen Yönünden Denetlenmesi" konulu 10/03/2016 tarihli ve 2852893 sayılı Genelgeler)" İfadesi birçok yönden incelenmesi gereken bir ifade örneğidir. Öncelikle ifadede parantezle belirtilen 2009/20 sayılı genelgeye MEB'in tüm genelgelerinin yer aldığı resmi sitesinden ulaşılamamıştır. Bu yönüyle rehber yasal belgelerle tutarsızlık kategorisinin "Yasal Dayanağa Internet Ortamında Ulaşılamaması" kodu altına girmektedir. Diğer taraftan İlgili ifadede geçen 2014/20 sayılı genelgeye internet ortamında ulaşılabilmekle beraber bu genelgenin isminin denetim rehberinde yer verilmemesi de bir eksiklik olduğu için yine Yasal belgelerle tutarsızlık kategorisi altında "Yasal Dayanağa Göre Eksik Ifade Edilmesi" kodu altına girmektedir. Öte yandan aynı örnek ifadede yer alan bir diğer genelgenin hem adının hem sayısının denetim rehberinde yer alması ve genelgeye internet ortamında kolaylıkla ulaşılabilmesi nedeniyle aynı ifade yasal belgelerle tutarlılık başlığı altında "yasal dayanağa uygunluk" kodu ile de tanımlanmıştır.

Geçerlik ve Güvenirlik: Bu araştırma nitel araştırma deseninde tasarlanmıştır. Nitel araştırmalarda iç geçerlik, dış geçerlik ve güvenirlik nicel çalışmalardan farklı olarak ele alınır (Yıldırım ve Şimşek, 2013). Bu çalışmada iç geçerliliği sağlamak için meslektaş teyidi ve uzman incelemesi yöntemleri kullanılmıştır. Araştırma kapsamında MEB Teftiş Kurulu Başkanlığı tarafından farklı kurumları denetlemek ve rehberlik etmek amacıyla hazırlanmış olan 16 rehberi inceleyen ve hepsi eğitim yönetimi alanından olan araştırmacılar (3 akademisyen, 2 doktora mezunu, 1 maarif müfettişi, 2 doktora öğrencisi, 4 tezli yüksek lisans öğrencisi) 12 hafta boyunca her hafta internet ortamında toplantı yaparak fikir alışverişi yapmış, fikir ayrışması yaşanan konularda ortak ve akılcıl çözümler bulunana kadar toplantılar devam ettirilmiştir. Toplantıların tekrar izlenebilmesi için toplantılar kaydedilmiştir. Araştırmacılar rehberin nasıl bir yol izlenerek en iyi şekilde incelenebileceği hakkında görüşler belirtmiş, bu görüşler doğrultusunda kodlar, kategoriler ve temalar oluşmuştur. İç geçerliği sağlamak için kullanılan bir diğer yöntem uzman incelemesidir. Araştırma konusu hakkında genel bilgiye sahip ve nitel araştırma yöntemleri konusunda uzmanlaşmış kişilerden, yapılan araştırmayı çeşitli boyutlarıyla incelemesinin istenmesi inanılırlık konusunda alınabilecek önlemlerden bir diğeridir. Bu yöntem, uzman incelemesi (peer debriefing) olarak adlandırılmaktadır (Creswell, 2003). Bu incelemede uzman, araştırmanın deseninden toplanan verilere, bunların analizine ve sonuçların yazımına kadar olan süreçlere eleştirel bir gözle bakar ve araştırmacıya geri bildirimde bulunur (Holloway ve Wheeler, 1996; Houser, 2015; Streubert ve Carpenter, 2011). Bu araştırmada kapsamında toplantılara katılan 3 akademisyen, 2 doktora mezunu ve 1 maarif müfettişi toplantılara katılarak geri bildirimlerde bulunmuşlardır. Ayrıca araştırma için yapılan toplantılar sona erdikten sonra alanında uzman akademisyenlere çalışma gönderilerek onların da görüşleri çalışmaya dahil edilmiştir. Diğer araştırmacıların talebi olursa veya gelecekte başka bir araştırmada karşılaştırma yapılması gerekirse diye araştırmanın ham verileri saklanmıştır 
böylece dış güvenilirlik (teyit edilebilirlik) arttırımaya çalışımıştır. Ayrıca araştırmanın güvenirliğini artırmak amacıyla ayrıntılı literatür taraması yapılmış, araştırma yöntemi ayrıntılı tanımlanmış ve başka araştırmacıların süreç ve sonuçları incelenmiştir (Başkale, 2016).

\section{BULGULAR VE YORUM}

Özel Öğrenci Etüt Eğitim Merkezleri Rehberlik ve Denetim Rehberi yasal belgeler ve alanyazın temelinde incelenmiştir. Yasal belgelerin analizi sonucunda şekillenen kategori ve kodlara ait frekans değerleri Tablo 2'de; alanyazındaki çalışmalar temelinde yapılan analiz sonucunda şekillenen kategori ve kodlara ait frekans değerleri Tablo 3'te verilmiştir.

\section{Denetim Rehberinin Yasal Belgelerle ilişkisi}

Tablo 2'de "Denetim Rehberinin Yasal Belgelerle Tutarlıı̆ı" ve "Denetim Rehberinin Yasal Belgelerle Tutarsızlı̆ı" kategorilerine ait kodlar ve bu kodların frekans değerlerine yer verilmiştir.

Tablo 2. "Özel Öğrenci Etüt Eğitim Merkezi Rehberlik ve Denetim Rehberinin" yasal belgeler temelinde analizi sonucu ortaya çıkan kategori ve kodlara ait dağılımı.

\begin{tabular}{|c|c|c|c|}
\hline Tema & Kategori & Kodlar & $f$ \\
\hline \multirow{7}{*}{ 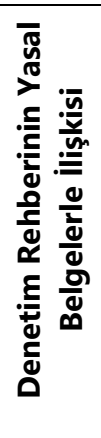 } & $\begin{array}{l}\text { 1. Denetim Rehberinin Yasal Belgelerle } \\
\text { Tutarlılığı }\end{array}$ & Yasal Dayanağa Uygunluk & 65 \\
\hline & 2. Denetim Rehberinin Yasal Belgelerle & $\begin{array}{l}\text { Yasal Dayanağa Eksik-Fazla-Hatalı } \\
\text { Gönderme Yapma }\end{array}$ & 14 \\
\hline & Tutarsızlığı & Mülga Maddelere Gönderme Yapma & 7 \\
\hline & & Yasal Boşluk & 6 \\
\hline & & $\begin{array}{l}\text { Yasal Dayanağa İnternette } \\
\text { Ulaşamama }\end{array}$ & 2 \\
\hline & & Normlar Hiyerarşisine Aykırılık & 2 \\
\hline & & Toplam & 96 \\
\hline
\end{tabular}

Tablo 2'ye bakıldığında, Denetim rehberinin yasal belgeler temelinde incelenmesi sonucu iki ana kategoriye ayrıldığı görülmektedir. "Denetim Rehberinin Yasal Belgelerle Tutarlılığı" kategorisinde "yasal dayanağa uygunluk $(n=65)$ " kodu yer alırken; "Denetim Rehberinin Yasal Belgelerle Tutarsılı̆̆ı" kategorisi "Yasal dayanağa eksik-fazla-hatalı gönderme yapma ( $n=14)$, mülga maddelere gönderme yapma $(n=7)$, yasal boşluk $(n=6)$, yasal dayanağa internette ulaşama $(n=2)$ ve normlar hiyerarşisine aykurllk $(n=2)$ " kodlarından oluşmaktadır.

\subsection{Denetim Rehberinin Yasal Belgelerle Tutarlılığı}

"Denetim Rehberinin Yasal Belgelerle Tutarlılığı" temasında yer alan "Yasal Dayanağa Uygunluk" kodu Denetim Rehberi'ndeki ifadeler ile bu ifadelerin gönderme yaptığı yasal kaynakların birbiriyle tutarlı ve birbirini tamamlayıcı olduğu durumlar için kullanılmıştır. Rehberde Yönetim faaliyetleri başlığı altında yer alan Öğrenci İşleri ile ilgili bir maddede: "Kurumda ücretsiz okutulacak öğrenci başvurularını değerlendirmek üzere Değerlendirme Kurulunun oluşturulması" ifadesiyle Özel Öğretim Kurumları Yönetmeliği Madde 59'a atıf yapılmaktadır. İlgili yönetmelik madde 59'da "(1) Kurumlarda, ücretsiz 
okumak için yapılan başvuruları değerlendirmek amacıyla Değerlendirme Kurulu oluşturulur. (2) Değerlendirme Kurulu, kurum müdürünün başkanlığında iki eğitim personelinden oluşur. (3) Değerlendirme Kurulu, dönem başlamadan toplanır ve Özel Öğretim Kurumlarında Ücretsiz Okuyacak Öğrenci ve Kursiyerler Başvuruları Değerlendirme Formuna göre başvuruları değerlendirip ücretsiz okuyacak öğrenci ve kursiyerleri tespit ederek ilgililere duyurur." Ifadesi yer almaktadır. Denetim Rehberinde yer alan ifade ile gönderme yapılan yasal belgenin ilgili maddesi birbiriyle ilişkili olduğundan bu ifade, "Denetim Rehberinin Yasal Belgelerle Tutarlılı̆ı" temasının "Yasal Dayanağa Uygunluk" kodu altında ele alınmıştır. Araştırma kapsamında incelenen 65 ifade bu şekilde yasal belgelerle tutarlı ve ilişkilidir. Bu koda ait ifadelerin sayıca fazla olmasının, yasal bir belge olan denetim rehberinin diğer yasal belgelerle temellendirilerek hazırlanması gerekliliğinden ve rehberin hazırlandığı 2014 yılında atıf yapılan yasal belgelerin birçoğunun güncelliğini korumasından kaynaklandığı söylenebilir.

2014 yılında MEB bünyesinde denetlenmesi gereken diğer kurumlarla birlikte Özel Öğrenci Etüt Merkezleri için de bir denetim rehberi hazırlanmıştır. Bu tarihte hazırlanan rehber o dönemin güncel yasal belgeleriyle temellendirilerek hazırlanmıştır. Fakat zaman içerisinde birçok kanun, yönerge ve yönetmeliğin ya tamamı kaldırılmış ya da bazı maddeleri değiştirilmiştir. Fakat denetim rehberi yaşanan değişikliklere göre güncellenmemiş, 2014 yılında hazırlandığı şekliyle bırakılmıştır. Böyle olunca 2014'te hazırlanan rehber günümüz ihtiyaçlarına cevap veremez olmuş, hazırlandığı yılda geçerli olan birçok maddenin geçersiz oluşu ya da değişmesiyle rehberde geçen bazı ifadelerle rehberin atıf yaptığı bazı yasal belgelerin birbiriyle uyuşmadığı görülmüştür. Rehberde bu durumdaki ifadeler çalışma kapsamında "denetim rehberinin yasal belgelerle tutarsızlığı" kategorisinde incelenmiştir.

\subsection{Denetim Rehberinin Yasal Belgelerle Tutarsızlığı}

"Denetim Rehberinin Yasal Belgelerle Tutarsızlığı" teması, "Yasal Dayanağa EksikFazla-Hatalı Gönderme Yapma, Mülga Maddelere Gönderme Yapma, Yasal Boşluk, Yasal Dayanağa internette Ulaşamama, Normlar Hiyerarşisine Aykırılık" kodlarından oluşmaktadır.

Denetim rehberi incelenirken, rehberdeki bazı ifadelerin yasal dayanaklara kimi zaman eksik, kimi zaman fazla kimi zaman ise hatalı olarak gönderme yaptığı söylenebilir. Her üç durumda da sorun ortak olduğu için üç durumu ifade eden kod olarak "Yasal Dayanağa Eksik-Fazla-Hatalı Gönderme Yapma $(n=14)$ kodu uygun görülmüş̧ür. Bu kod denetim rehberinin yasal belgelerle tutarsızlığı kategorisinde en yüksek frekansa sahip olan koddur. Rehberdeki ifadenin gönderme yaptığı yasal belgedeki ilgili madde dışında, diğer maddelere de atıf yapılması gerekiyorsa ya da atıf yapılan yasal belge dışında başka yasal belgelere de atıf yapma gerekliliği oluşmuşsa bu durum yasal dayanağa eksik gönderme yapıldığının göstergesidir. Denetim rehberinde eğitim-öğretim ortamları, okulun fiziki koşullarının yeterlik durumu başlığı altında yer alan "Kurumun yerleşim planına göre derslik, oda ve diğer bölümlerin düzenlenmesi, dersliklerde yerleşim planlarında belirtilen kontenjandan fazla öğrenci bulundurulmaması, onaylanan yerleşim planlarında belirtilen bölümlerin amaçları dışında kullanılmaması" ifadesi Özel Öğretim Kurumları Yönetmeliği Md.5/d bendine gönderme yapmaktadır. Illgili yönetmelik maddesi: "Binanın kurum açılacak kat veya katları için ayrı ayrı, okul ve özel eğitim ve rehabilitasyon merkezi olarak kullanılacak 
binaların ayrıca bahçeleri için de $35 \times 50 \mathrm{~cm}$ veya A3 ebadında kâğıtlara çizilmiş yerleşim planı, binanın dış cepheleri ile bahçesini gösteren fotoğrafları ve CD'si." şeklindedir. Rehberin gönderme yaptığı yasal belgede, rehberde belirtilen "Dersliklerde bulundurulması gereken öğrenci sayısı" ile ilgili bir ibareye rastlanamamaktadır. 05/03/2010 tarihinde yürürlükten kaldırılan, 18/08/2015 tarihinde güncellenerek tekrar yürürlüğe giren ve son olarak 19/02/2020 tarihli ve 31044 sayılı resmi gazetede yayınlanan güncel Özel Öğretim Kurumları Standartlar Yönergesi madde 8'de "Okullarda ve okullar dışındaki diğer kurumların uygulama dersliklerinde bir öğrenci için ayrılan kullanım alanı 1,2 $\mathrm{m}^{2}$ den az olamaz." Ifadesi yer almaktadır (Resmi Gazete,2020).

Özel Öğretim Kurumlarına Ait Standartlar Yönergesinin 2010 yılında yürürlükten kaldırılmasıyla 18/08/2015 tarihinde güncel yönergenin yayınlanması arasında geçen süre bu kurumlar için bir eksiklik olarak görülmektedir. 2014 yılında yayınlanan denetim rehberi de bu yönerge boşluğunun olduğu döneme denk geldiğinden, rehber hazırlanırken yürürlükten kaldırılan yönergeye sıkça gönderme yapılmıştır. Bu da yasal bir belge olan denetim rehberinin aslında var olmayan bir yönergeye gönderme yapmasından dolayı bir eksiklik olarak görülmektedir.

"Mülga maddelere gönderme yapma $(n=7)$ " kodu, rehberde geçen ifadelerin gönderme yaptığı yasal kaynağın güncelliğini yitirdiği durumlarda kullanılmıştır. Rehberde yer alan kurumun fiziki koşullarının yeterlik durumu başlığı altında yer alan, "Dersliklere Atatürk resmi, İstiklal Marşı ve Gençliğe Hitabe levhalarının asılması; kurucu, müdür, müdür yardımcısı, büro hizmetleri, öğretmenler ve yardımcı hizmetli odalarında Atatürk resminin bulunması" ifadesi MEB Kurum Tanıtım Yönetmeliği Md.8 ve Özel Öğretim Kurumları Standartlar Yönergesi Md.32'e gönderme yapmaktadır. Özel Öğretim Kurumları Standartlar Yönergesi rehber hazırlandığı dönemde yürürlükten kaldırılmış bir yönerge olmakla birlikte rehberde geçen ifadede gönderme yapılan madde 32'de Atatürk Köşesi'nden hiç bahsedilmemektedir. Rehber güncel olmayan bir yönergenin mülga bir maddesine gönderme yapmaktadır. MEB Kurum Tanıtım Yönetmeliği ilgili maddede ise sadece Atatürk köşesindeki resim ve bayrakların niteliği hakkında bilgi verilmiştir.

"Yasal boşluk $(n=6)$ " kodu, rehberde geçen ifadelere yönelik herhangi bir yasal belge olmadığı durumlarda kullanılmıştır. Rehberde eğitim faaliyetleri başlığı altında yer alan, "Panolara asılan resim, tablo, harita ve diğer dokümanların eğitim amaçlı olması" ifadesinin gönderme yaptığı herhangi bir yasal dayanak yoktur. Hangi görselin ne kadar eğitici olduğuna dair yasal bir dayanak ya da standart belirtilmediği için panolara asılan dokümanların eğitim amaçlı olup olmadığına karar verme mekanizması olarak durum kurumların inisiyatifine bırakılmıştır. Bu yasal boşluk eğitimde büyük yere sahip olan görsellerin hangi amaçla ve nasıl kullanılacağına dair keyfiyet yarattığından uygulamada birlik sağlanması hususunda sorun yaratabilmektedir (Akçay Güngör ve Tonbul, 2017).

"Yasal dayanağa internette ulaşama $(n=2)$ " kodu, rehberde gönderme yapılan yasal belgeye internet ortamında ulaşılamadığı durumlarda kullanılmıştır. Rehberde yer alan "Kantinlerin denetimi ve hijyen kurallarına uyulması, uyuşturucu kullanımı ve bağımlılı ile mücadele" ifadesi 2009/20 sayılı MEB genelgesine gönderme yapmaktadır. Tüm genelgelerin yer aldığı bakanlığın resmi MEB Mevzuat sitesinde ifadenin gönderme yaptığı sayılı genelgeye ulaşılamamıştır.

Denetim rehberinde tespit edilen bir diğer tutarsızlık "Normlar Hiyerarşisine Aykırılık $(n=2)$ "tır. Normlar hiyerarşisi hukuk düzeni piramididir. Hukuk sistemi 
içerisinde bulunan anayasa, kanun, tüzük, yönetmelik ve benzeri normlar birbiriyle bağlantılı ve birbirinin devamı niteliğinde olmalıdır. Normların birbiriyle altlık-üstlük ilişkisi içerisinde olmasıdır. İncelenen denetim rehberinde eğitim-öğretim ortamları ana başlığının altında yer alan okulun fiziki koşullarının yeterlik durumu ile ilgili ifadede: "Kurumun bulunduğu binada; meyhane, kahvehane, kuraathane, bar, elektronik oyun merkezleri gibi umuma açık yerler ile açık alkollü içki satılan yerlerin bulunmaması" denilmiş ve Özel Öğretim Kurumları Kanunu Md.4'e gönderme yapılmıştır. İlgili kanun maddesinde ise; "Meyhane, kahvehane, kuraathane, bar, elektronik oyun merkezleri gibi umuma açık yerler ile açık alkollü içki satılan yerlerin, okul binalarından kapıdan kapıya en az yüz metre uzaklıkta bulunması zorunludur. Özel eğitime muhtaç bireylerin devam ettikleri öğretim kurumları ile okullar dışındaki diğer özel öğretim kurumlarında bu zorunluluk aranmaz. Ancak, söz konusu özel öğretim kurumlarıla yukarıda belirtilen türdeki iş yerleri aynı binada bulunamaz. Turizmin yoğun olduğu yörelerde bulunan okulların tatil olduğu dönemlerde, yukarıda belirtilen iş yerleri ile okullar arasında yüz metre uzaklık şartı aranmaz." denilmektedir. Türkiye Cumhuriyeti Anayasası madde 42 'de "Devlet durumları sebebiyle özel eğitim ve ögrenime ihtiyacı olanları topluma yararlı kılmak için gerekli tedbirleri alır." ifadesiyle eğitimde eşitlik ve genellik ilkesine vurgu yapılmaktadır. Ayrıca, 1739 Milli eğitim temel kanunu madde 4'te genellik ve eşitlik, madde 8'de fırsat ve imkân eşitliğine vurgu yapılırken hiçbir bireyin dil, din, ırk, engellilik gibi durumlardan dolayı ayrıma uğramayacağı, her bireyin eşit şartlarda eğitim görmesi gerekliliği ifadesi yer alır. Özel Öğretim Kurumları Kanununda bunun tam tersi olarak öğrenciler için uygun olmayan alkollü mekânlar için normal okullarda 100 metre kuralı varken özel eğitime muhtaç bireyler için kuralın ihlal edilmesi üst yasal belgelerde güvence altına alınan eğitimde eşitlik ve erişilebilirlik ilkesine aykırıdır.

\section{Denetim Rehberinin Alanyazınla ílişkisi}

Tablo 3'te "Denetim rehberinin alanyazınla ilişkisi teması" altında "Denetim rehberinin alanyazınla tutarlıı̆̆ı" ve "Denetim rehberinin alanyazınla tutarsızlı̆̆ı" kategorilerine ait kodlar verilmiştir. Alanyazında denetim rehberi ve eğitim kurumlarının birlikte ele alındığı az sayıda çalışma olmasından dolayı, dolaylı olarak ilgili olan çalışmalar incelenmiş ve veriler sayısallaştırmaya gidilmemiştir.

Tablo 3. "Denetim rehberinin alanyazınla ilişkisi" teması altında ortaya çıkan kategori ve kodların dağılımı

\begin{tabular}{|c|c|c|}
\hline Tema & Kategoriler & Kodlar \\
\hline$\underline{E}=\widetilde{\sigma}$ & $\begin{array}{l}\text { 1.Denetim Rehberinin Alanyazınla } \\
\text { Tutarlılığ }\end{array}$ & Uygunluk \\
\hline 苋 & $\begin{array}{l}\text { 2.Denetim Rehberinin Alanyazınla } \\
\text { Tutarsızlı̆ı }\end{array}$ & $\begin{array}{l}\text { Atıfsızlık } \\
\text { Aykırılık } \\
\text { İçerik eksikliği }\end{array}$ \\
\hline
\end{tabular}

\subsection{Denetim Rehberinin Alanyazınla Tutarlılığı}

Denetim rehberinde yer alan ifadelerin analiz edilmesi sonucu rehberin genel olarak alanyazında denetim rehberlerleriyle ilgili yapılan çalışmalarla tutarlı olduğu söylenebilir. Bunun gerekçesi olarak da hem alanyazında yer alan bilimsel çalışmaların hem de yasa, yönetmelik, yönerge gibi yasal belgelerin bilim temelli oluşturulması ve 
ilerlemesidir. Denetim rehberinde yer alan "Rehberlik ve Denetim Raporlama Standartları" başlığında; "Denetim ve rehberlik faaliyeti bittikten sonra yapılacak raporlama işlemlerinde denetim ilke ve esasları ile raporlama standartları dikkate alınarak denetim raporu yazılır. Denetim raporları doğruluk, tarafsızlık, açıklık, ölçülebilirlik, özlük, yapıcılık, tamlık ve zamanlılı ilkelerine uygun olarak yazılmalıdır." İfadesi verilmiş ve bu kavramların tek tek önemi açıklanmıştır. Bu ilkeler herhangi bir bilimsel çalışmayı raporlarken de uyulması gereken ilkelerdir ve alanyazınla doğrudan ilişkilidir. Bu ifade "Denetim Rehberinin Alanyazınla Tutarlılk" temasının "uygunluk" koduna örnek verilebilir. Denetim rehberindeki ifadelerin genel anlamda alanyazınla tutarlı oluşu eğitim denetiminde bilimselliğin önemini aktif tutmak açısından önemli bir bulgudur.

\subsection{Denetim Rehberinin Alanyazınla Tutarsızlığı}

Denetim rehberindeki ifadelerin incelenmesi sonucu bazı ifadelerin alanyazınla tutarsız olduğu sonucuna ulaşılmıştır. Bu tutarsızlıklar Tablo 3 'te de görüldüğü üzere; atıfsızlık, içerik eksikliği, aykırılık kodlarıyla tasniflenmiştir.

"Denetim rehberinin alanyazınla tutarsızlı̆ı" kategorisinde en çok göze çarpan "Atıfsılık" kodudur. Bu kod rehberin alanyazınla ilişkisi ister tutarlı ister tutarsız olsun rehberin konusu ile ilgili yapılmış bilimsel çalışmalara gönderme yapılmaması durumunu ifade etmektedir. Denetim rehberinde özellikle rehberlikle ilgili kısımlarda bahsi geçen konu ile ilgili alanyazında yapılmış bilimsel çalışmalara -alanla ilgili araştırmalara, kitaplara, makalelere v.b.- gönderme yapılmaması durumunda tercih edilmiştir. Bu bulgunun gerekçesi olarak rehberin hazırlanırken sadece mevzuatın göz önünde bulundurulması ve bilimsel bilginin göz ardı edilmesi şeklinde açıklanabilir. Diğer yandan rehberin var olan haliyle alanyazınla tutarlı çıkan yanları itibariyle o kısımların gönderme yaptığı mevzuatın şekillenişi ya da oluşturulması esnasında bilimsel bilgiden hareket edilmiş olabileceğine ilişkin bir ipucu da verebilir.

Denetim rehberinde denetlenmesi gereken birimler ve faaliyetlere yönelik sorunlar ve çözüm önerileri başlıkları oluşturulmuştur. Sorun başıklarının tümünde "Sorunlar tespit edilirken; mevzuat, üst politika belgelerinde (Kalkınma Planı, Hükümet Programı, Millî Eğitim Bakanlı̆ı Stratejik Planı) eğitim ile ilgili ortaya konulmuş amaç ve hedefler göz önünde bulundurulur." Ifadesi yer almaktadır. Yani bir eğitim kurumunun sorunları tespit edilirken sadece üst politika belgeleri esas alınmakta; o alanla ilgili yapılan bilimsel çalışmalar göz ardı edilmektedir. Çözüm önerileri başlıklarının tümünde: "Kuruma yönelik olarak; kurumun gelişimine katkı sağlayacak, değer katacak, geleceğe ilişkin bir vizyon oluşturacak, aynı zamanda gerçekçi ve uygulanabilir önerilere yer verilmelidir." Ifadesi tekrar edilmiştir. Bu çok soyut ve genel bir ifadedir. Bunun yerine o birim veya başıkla ilgili alanyazında yer alan herhangi bir bilimsel çalışmaya atıf yapılarak hem denetmene yol gösterilebilir hem de denetimin daha bilimsel temellere dayandırılması sağlanabilirdi. Böylece rehber sadece mevzuat odaklı değil, bilimsel bilginin de temele alındığı bir kaynak haline getirilebilirdi. Eğitbilimciler eğitim pratiğinin teorilerini hazırladıklarında, bu teoriler üretildiği toplumun ve belki de uluslararası toplumun gerçekten (hukuksal anlamda) yasal belgelerine yansıdığında ancak (o ülkede ya da dünyada) eğitimin bilimliliğinden söz edilebilir (Toprakçı, 2008; Toprakçı, Dağdeviren, Oflaz ve Türe 2010). Eğitim denetimi akademisyenlerinin ürettiği bilginin işlerliği açısından uygulamadakilerin onların çalışmalarından atıf yaparak yararlanmaları hem uygulamaya nitelik kazandırmak hem de akademisyeni takdir etmek 
bağlamlı katkı sağlayıcı olabilir.

Denetim Rehberinin Alanyazınla Tutarsızlığı kategorisinde göze çarpan bir diğer kod "Aykırılık"tır. Aykırılık kodu, denetim rehberi ile alanyazın arasında uyuşmayan durumlar gözlemlendiğinde kullanılmıştır. Rehberde denetim ve rehberlik kavramları ayrı ayrı tanımlanmakta ve sürekli birbirlerinden çok farklı ve birbirleriyle ilişkisiz kavramlarmış gibi ayrı başlıklarda ele alınmaktadır. Oysa alanyazına bakıldığında denetim; durum saptama, değerlendirme, düzeltme ve geliştirme olmak üzere üç aşamadan oluşmaktadır ( Aydın, 2019). Son aşama olan düzeltme ve geliştirme aşaması denetimin rehberlik boyutunu oluşturmaktadır. Yani denetim ve rehberlik birbirini tamamlayan ve iç içe geçmiş kavramlardır. Bu yönüyle rehber alanyazınla çelişmektedir.

Denetim rehberinde tespit edilen bir diğer kod, "içerik eksikliği" kodudur. İçerik eksikliği alanyazında var olan fakat denetim rehberinde ihtiyaç duyulan yerlerde kullanılmayan bilimsel ifadeler, terimler, durumlar v.b. için kullanılmıştır. Denetim rehberinin "Rehberlik ve Denetim ilkeleri" başlığında birçok denetim ilkesine yer verilmiş ve bu ilkeler açıklanmıştır. Aydın (2019)'a göre, rehberlik ve denetim ilkelerinde yer alan "durumsallık, bütünlük, süreklilik, planlılı ve amaçlılık" gibi kavramlara denetim rehberinin ilgili başlığında hiç değinilmediği görülmüştür. Denetimin hangi ilkelere göre yürütüleceği şüphesiz oldukça önemlidir. Özel öğrenci etüt merkezlerinin de denetlenirken alanyazında kabul görmüş denetim ilkelerinin esas alınarak denetlenmesi yapılan denetimin bilimselliği açısından oldukça önemlidir.

\section{SONUÇ VE ÖNERILER}

Araştırmanın bu bölümünde analizlerden elde edilen tema, kategori ve kodlara ait bulgulardan çıkarılan sonuçlar ve bu sonuçlardan yola çıkarak araştırmacı ve uygulayıcılara sunulabilecek önerilere yer verilmiştir.

Türk denetim sistemi ve Özel öğrenci etüt merkezleriyle ilgili alanyazın incelendiğinde sınırlı sayıda çalışma yapıldığı tespit edilmiştir. Durnalı ve Limon (2018)'a göre, Milli Eğitim Bakanlığı Teftiş Kurulu Başkanlığı'nın temel faaliyet alanlarından birinin de özel öğrenci etüt eğitim merkezleri olduğu belirtilmiş, bakanlık merkez ve taşra teşkilatının yapısında, işleyişinde ve bu denetim sistemi içerisinde rolleri üstlenen müfettişlerin görev kapsamı ve unvanlarında, başkanlıkların isimlerinde değişikliklerin çok sık yapıldığı bulgusuna ulaşılmıştır. Benzer şekilde Altınışık ve Binbir (2015)'in araştırma bulgularına göre 2000- 2014 yılları arasında Türk Eğitim Sisteminde mevzuatların sıklıkla değiştirildiği bulgusuna ulaşılmıştır. Bu durum gerek ilgili kurum personelinin, gerek sıradan vatandaşların ve konuyla ilgili bilim insanlarının bireysel hafızasını, konuya ilişkin sahip oldukları bilgi kümelerindeki bilgilerin gerçeklik ve doğruluğunu oldukça zorlayabileceği, bu kadar sık değişiklik yapılmasının en önemli gerekçesi olarak da Milli Eğitim Bakanı́nın ve dolayısıyla da bürokratların değişmesi olduğu sonucuna ulaşılmıştır. Turan (2016)'ın okul öncesi denetim rehberiyle ilgili araştırma bulgularına göre, rehberde kurumun denetimine esas teşkil eden standartlara ilişkin sınıflandırmanın, kurumun işleyişini tüm yönleri ile kapsayacak özellikte olmadığı, bazı standartların farklı başıılar altında tekrarlandığı ve birçok standardın, ayrı ayrı incelenip değerlendirilmesi gereken birden çok göstergeyi içinde bulunduracak şekilde yazıldığı görülmektedir (MEB, 2014) Bu durumun denetimin güvenirliğini zayıflattığl; denetimin niteliğini olumsuz etkilediği söylenebilir. Aynı standart içerisinde birçok göstergenin yer alması, denetim raporlarında birden çok göstergeyi kapsayan 
standardın, çözümlenmeden değerlendirilmesine neden olabilmektedir. Dolayısıyla kurum hakkında birçok tespit ve değerlendirmenin, açık ve anlaşılır olmaktan uzak bir şekilde raporlarda yer aldığı ve bu durumun, denetimden beklenen faydayı sınırlandırdığı sonucuna ulaşılmıştır. Yasal belgeler temelinde yapılan eğitim denetimi araştırmaları incelendiğinde Türkiye'deki bakanlıkların eğitim yönetimi ve denetimi alanındaki uygulamaları (Toprakçı ve Kadı, 2014) kamu yararına çalışan derneklerin eğitim faaliyetlerinin yönetimi ve denetimi (Toprakçı ve Akçay, 2016), sivil toplum örgütlerinin eğitim amaçlı faaliyetlerinin denetlenmesi (Çankaya, 2015), sendikaların eğitsel faaliyetlerinin yönetimi ve denetimi (Toprakçı ve Arslan, 2016), Türkiye'deki siyasi partilerin eğitim politikalarında eğitimin yönetimi ve denetimi (Toprakçı ve Akçay Güngör, 2014) Milli Eğitim Bakanlığı Sayıştay denetim raporlarının (Toprakçı ve Bakır, 2019) ve Yargıtay'ın özel öğretim kurumlarına ilişkin verdiği kararların incelenmesi (Toprakçı, Beytekin ve Doğan, 2018) gibi konularda yapılan araştırmalar Türk eğitim sisteminde yönetim ve denetimin yasal dayanakları esas alarak irdelendiği araştırmalardır.

Özel öğrenci etüt eğitim merkezi rehberlik ve denetim rehberi incelendiğinde rehberin genel olarak yasal belgelerle tutarlı olduğu görülmüştür. Milli Eğitim Bakanlığı Rehberlik ve Denetim Başkanlığı tarafından hazırlanan bu rehberin yasal belgelerle tutarlı olması beklenen bir sonuç olmakla beraber bu tutarlılığın devam etmesi için rehberi hazırlayanların ve uygulayıcı olan denetmenlerin güncel yasal gelişmelerden anında haberdar olmaları için internet ortamında bir platform oluşturulabilir.

Eğitim ve denetimle ilgili yasal belgelerin sayısı oldukça fazladır ve her geçen gün artmaya devam etmektedir. Hazırlanan denetim rehberlerinin yasal belgelerle tutarlılığının devamlılığı ve her daim güncelliğini koruması için ne gibi önlemler alınabileceği, güncel denetim rehberinin müfettişlerce ne ölçüde kullanıldığı ile ilgili maarif müfettişlerini de kapsayan bir çalışma yapılması araştırmacılara önerilebilir.

Incelenen denetim rehberinde yasal belgelerle tutarsız olan birçok nokta da tespit edilmiştir. Bu tutarsızlıkların en temel nedeni hazırlanan denetim rehberinin sadece hazırlandığı dönemi kapsayacak şekilde kalması, yasal değişmelere ve gelişmelere yetişememesidir. Rehberi hazırlayanlara rehberin içeriğinde bulunan yasal belgelerin değişimi ve güncelliğini takip etmeleri ve yeni yasalar çıktıkça rehberi güncelleştirmeleri önerilebilir. Mülga olan maddelerin veya yürürlükten kaldırılan yasal belgelerin anında Teftiş Kurulu Başkanlığı resmi sitesinde yayınlanması önerilebilir. Araştırmacılara ise modern çağda her tür eğitim kurumunda denetmenlerce kullanılan denetim rehberinin nasıl daha işlevsel, açık, kullanışlı ve ulaşılabilir hale getirilebileceği ve rehberin nitelik ve niceliğinin nasıl arttırılabileceği hakkında araştırma yapmaları önerebilir.

Denetim rehberinin yasal belgelerle tutarsız olduğu noktalardan bir diğeri de rehber hazırlanırken normlar hiyerarşisine dikkat edilmemesi ve rehberde yasal boşlukların olmasıdır. Bu durumun engellenmesi için rehberi hazırlayanların yasaları bilen kişiler arasından seçilmesi önerilebilir. Uygulayıcı olan denetmenlere de yine bu hukuksal terimlere ve yasalara hakim hukukçular tarafından eğitim verilmesi ve üniversitelerin eğitim yönetimi bölümlerindeki denetim ders içeriklerinin bu şekilde güncellenmesi de önerilebilir. Araştırmacılar eğitim denetmenlerinin hukuksal bilgilerinin ne düzeyde olduğunu ya da eğitim denetimi alanındaki güncel yasal gelişmelerden ne derece haberdar olduklarını belirlemeye yönelik araştırmalar yapmaları önerilebilir.

Denetim rehberinin genel anlamda alanyazınla tutarlı olduğu söylenebilir. 
Özellikle rehberde yer alan birçok tanımın alanyazından alındığı söylenebilir. Bu tutarlıı̆ın devam etmesi için rehberi hazırlayanların alanyazındaki gelişmelere ve yeni bilimsel bilgilere ulaşabilir ve ulaştığı bilgileri yorumlamaya muktedir kişilerden seçilmesi önerilebilir. Ayrıca denetim rehberleri güncellenmeden önce alandan akademisyenlerin de katılım sağlayacağı konferans, panel, sempozyum, çalıştay gibi etkinlikler yapılabilir. İyi bir denetim rehberinin kimler tarafından nasıl yazılması gerekliliği varsa farklı ülkelerdeki rehberlerle karşılaştırılmasının da araştırmacılar tarafından araştırılması önerilebilir.

İncelenen denetim rehberinin bazı noktalarda alanyazınla tutarsız olduğu görülmüştür. Rehberde alanyazından birçok tanım ve terim kaynak gösterilmeden kullanılmıştır. Bazı terimlerin ise alanyazındaki değişmelerden habersiz olarak geçmişte geçerli olan bilgiler doğrultusunda kullanıldığı; modern denetimden ziyade klasikbürokratik teftiş kavramlarına rehberde yer verildiği görülmüştür. Ayrıca rehberde yer alan başlıklara bakıldığında denetlenen kurumların sadece kurum olarak görüldügü̈; kurumdaki kişilerin pedagojik ve yönetsel yetkinliklerinin göz ardı edildiği görülmektedir. Bu durum da daimici bir yaklaşımla hazırlanan denetim rehberinin güncelliğini ve işlevselliğini tehlikeye düşürmektedir. Uygulayıcılara rehberi hazırlayanlara yönelik dünyada eğitim denetimi alanındaki yenilikleri, gelişmeleri, eğitimleri takip etmelerini sağlayacak bir uzaktan eğitim platformu sağlamaları önerilebilir. Araştırmacılara ise devlet kurumlarının çağın ve alanyazının gerisinde kalma nedenleri ve nasıl önlenebileceği ile ilgili araştırmalar da yapmaları önerilebilir.

\section{KAYNAKLAR}

Güngör, A., A. ve Tonbul, Y.(2017). An Analysis of The Permanent Visuals in Primary Schools According Their Topic, Utility and Effectiveness. Kastamonu Eğitim Dergisi, 25 (2). e-ISSN 21479844.

Akkaş, F.,Aksu, A., Yurttaş, A.,Yııdııım, S. (2019). Kliniksel Denetim Yaklaşımı Bağlamında Illkokul Müdürlerinin Ders Denetimi Faaliyetleri. Turkish Studies Educational Siences, 14 (4). ISSN: 2667-5609.

Aksu, A., İra, N., Çek, F. (2012). Stratejik Liderliğe iliş̧kin Denetmen Görüşleri (İzmir il Örneği). İönü Üniversitesi Eğitim Fakültesi Dergisi, 13 (1), 59-80, ISSN: 1300-2899.

Aksu, A., Yımaz, A.I.., Orçan, A. (2016). Denetimde Bilgi Uçurma. Kastamonu Eğitim Dergisi, 24 (4). 1727-1748.

Altınışık, S ve Binbir, Ü. (2015). Son on beş yılda Türkiye'de eğitim denetimine ilişkin yapılan tezlerin analizi, M. B. Aksu ve H. Şimşek (Ed.), Eğitim ve Toplum Yazıları. İçinde (83-104). Ankara: Gazi Kitapevi.

Argyris, C. (1993). Knowledge for action: A guide for overcoming barriers to organizational change. San Francisco, CA: Jossey-Boss.

Aydın, M. (2014). Çağdaş eğitim denetimi. Ankara: Gazi Kitabevi.

Aydın, İ. (2019). Öğretimde denetim: durum saptama, değerlendirme ve geliştirme. Ankara: Pegem A yayınları.

Başkale, H. (2016). Nitel Araştırmalarda Geçerlik, Güvenirlik ve Örneklem Büyüklüğünün Belirlenmesi. Dokuz Eylül Üniversitesi Hemşirelik Fakültesi Elektronik Dergisi, 9(1), 23-28.

Bowen, G. A. (2009). Document Analysis As A Qualitative Research Method. Qualitative Research Journal, 9(2), 27-40.

Bursalıoğlu, Z. (2015). Okul yönetiminde yeni yapı ve davranış (19. Baskı). Ankara: Pegem A Yayınları.

Creswell, J. W. (2003). Research design: Qualitative, quantitative and mixed methods approaches. California: Sage Publications.

Çankaya, İ. (2005). Sivil Toplum Örgütlerinin Eğitim Amaçı Faaliyetleri. Yüksek Lisans Tezi, Fırat Üniversitesi, Sosyal Bilimler Enstitüsü. Elazığ. 
Demirtaş, Z. ve Ersözlü, A. (2007). Illköğretim Okulu Öğretmenlerinin Görüşleri Bağlamında Teftiş Sürecinde Etik (Tokat Ili Örneği). Doğu Anadolu Bölgesi Araşttrmaları 6 (1), 89-94.

Durnalı, M., ve Limon, i. (2018). Çağdaş Türk Eğitim Denetimi Sistemi (Değişimler Ve Yasal Dayanakları). Kastamonu Education Journal, 26(2), 413-425. doi:10.24106/kefdergi.389801.

Erdem, A. R. (2008). Eğitimin denetimsel temelleri, V. Sönmez (Ed.), Eğitim Bilimine Giriş içinde ss: 241260, Ankara: Anı Yayıncılık.

Erdem, A.R. ve Sarpkaya, R. (2011). Postmodernizmin Eğitim Denetimine Uygulanabilirliği. Mehmet Akif Ersoy Üniversitesi Sosyal Bilimler Enstitüsü Dergisi, 3(4), 73-85. SSN:1309-1387.

Falkingham, L. T.; Reeves, R.(1998). Context Analysis: A Technique for Analyzing Research in A Field, Applied to Literature on The Management of R\&D At The Section Level. Scientometrics, 42(2), 97-120.

Forster, N. (1994). The analysis of company documentaion. C. Cassell and G. Symon (Eds.) Qualitative methods in organizational research: A pratical quide. London: Sage Pub.

Glatter, R. ve Kydd, L. (2003). Best Practice' İn Educational Leadership And Management: Can We Identify It and Learn from It? Educational Management Administration Leadership, 31(3) 231243, DOI: 10.1177/0263211X03031003002.

Gökçe, F. (1994). Eğitimde Denetimin Amaç ve Illkeleri. Hacettepe Üniversitesi Eğitim Fakültesi Dergisi. 10, 73-78.

Holloway, I.,ve Wheeler, S. (1996). Qualitative research for nurses. Oxford: Blackwell Science Ltd.

Houser, J. (2015). Nursing research: Reading, using, and creating evidence. (3rd ed.). Burlington: Jones ve Bartlett Learning.

Kesik, F., Aksu, A. (2015). Eleştirel Kuram Perspektifinden Eğitim Denetimine iliş̧kin Bir Değerlendirme. International Journal of Human Sciences 12(1), ISSN:1303-5134.

Madge, J. (1965). The tools of science an analytical description of social scince techniques. New Yorke: Anchor Books Doubleday and Comp.

Milli Eğitim Bakanlığı Okulöncesi Eğitim Kurumları Rehberlik ve Denetim Rehberi. (2016) https://tkb.meb.gov.tr/meb_iys_dosyalar/2016_11/14010033_okuloncesi_egitim_kurumlari_rehb erlik_ve_denetim_rehberi_2016.doc

Milli Eğitim Bakanlığı Okul Kantinlerinde Satılacak Gıdalar ve Eğitim Kurumlarındaki Gıda İsletmelerinin Hijyen Yönünden Denetlenmesi Konulu Genelge. (2016 Mart 10) . Genelge (Sayl:2852893). https://www.resmigazete.gov.tr/eskiler/2019/06/20190620-5.htm

Milli Eğitim Bakanlığı Özel Öğrenci Etüt Eğitim Merkezleri Rehberlik ve Denetim Rehberi. (2016) http://tkb.meb.gov.tr/www/yayinlarimiz/icerik/13

Millî Eğitim Bakanlığı Özel Öğrenci Etüt Eğitim Merkezleri Yönetmeliği.(2011,Haziran 24). Resmi Gazete (Sayı:27974). https://www.resmigazete.gov.tr/eskiler/2011/06/20110624-2.htm

Millî Eğitim Bakanlı̆̆ı Özel Öğretim Kurumları Yönetmeliğinde Değişiklik Yapılmasına Dair Yönetmelik.(2020, Şubat 19). Resmi Gazete (Sayı:31044). https://www.resmigazete.gov.tr/eskiler/2017/06/20170620-1.htm

Oktar, A. N. (2010). Eğitim Denetimi Sisteminin Yasal Dayanaklara Göre Değerlendirilmesi. Yüksek Lisans Tezi. Dokuz Eylül Üniversitesi, Eğitim Bilimleri Enstitüsü, İzmir.

Öz, F. (2003). Türkiye Cumhuriyeti milli eğitim sisteminde teftiş. Eskişehir: Osmangazi Üniversitesi Yayınları.

Özen, F. ve Hendekçi, E. A. (2016).Türkiye'de Eğitim Denetimi Alanında 2005-2015 Yılları Arasında Yayımlanan Makale ve Tezlerin Betimsel Analizi. Uluslararası Toplum Araştırmaları DergisiInternational Journal of Society Researches 6(11), 621-650. ISSN:2528-9527 E-ISSN: 2528-9535

Özmen, F. ve Yasan, T. (2007) Türk Eğitim Sisteminde Denetim ve Avrupa Birliği Ülkeleriyle Karşılaştırılması. Doğu Anadolu Bölgesi Araştırmaları, 6(1), 204-210.

Streubert, H. J., Carpenter, D. R. (2011). Qualitative research in nursing. (5th ed.). Philadelphia: Lippincott Williams ve Wilkins.

Şişman, M. (2011). Öğretim liderliği (3.Baskı). Ankara: Pegem A Yayınları.

Toprakçı, E. (2008). Sınıfa dayalı yönetim. Ankara: Pegem Akademi Yayıncılık.

Toprakçı, E.(2013). Sınıf yönetimi, Ankara: PegemA Yayınları. ISBN 978-605-364-458-3470.

Toprakçı, E. ve Akçay, A. (2016). Türkiye'de Kamu Yararına Çalışan Derneklerin Eğitim Faaliyetlerinin Yönetimi ve Denetimi (Yasal Belgeleri Temelinde Nitel Bir Analiz). Cumhuriyet International Journal of Education-CIJE, 5(1), 29-52. 
Toprakcı, E. ve Güngör, A., A. (2014). Türkiye'deki Siyasal Partilerin Eğitim Politikaları. Educational Policy Analysis and Strategic Research, 9, 5-35.

Toprakcı, E.,Arslan, M., (2016). Yönetim Süreci Bağlamında Sendikalardaki Eğitsel Faaliyetlerin Yönetimi Yasal Belgeler Temelinde Nitel Bir Analiz. Çağdaş Yönetim Bilimleri Dergisi, 2, $1-13$.

Toprakçı, E. ve Bakır, D. (2019). 2012-2017 Yılları Arası Milli Eğitim Bakanlığı Sayıştay Denetim Raporlarının Incelenmesi. Y. Kondakçı, S. Emil ve K. Beycioğlu (Ed.) 14. Uluslararası Eğitim Yönetimi Kongresi içinde (s. 829-834). Ankara: Orta Doğu Teknik Üniversitesi.

Toprakcı, E., Beytekin, O. F., Doğan, M., (2018). Yargıtayın Özel Öğretim Kurumlarına İlişkin Verdiği Kararların İncelenmesi. Turkish Studies Educational Sciences,13, 1781-1795.

Toprakçı, E., Çakırer, I., Bilbay, A., Bagcivan, E. ve Bayraktutan, I. (2010). Kuram ve Uygulamada Eğitim Denetmenleri Meslek Etiği. Educational Policy Analysis and Strategic Research, $5(1)$.

Toprakçı, E. Dağdeviren, İ. Oflaz, G ve Türe, E. (2010) Eğitim Fakültesi Öğretim Elemanlarının Bilim Anlayışları Temelinde Eğitimin Bilimliliği, Bilim ve Ütopya Dergisi, 190, 45-56.

Toprakçı, E. ve Kadı, A. (2014). Türkiye'deki Bakanlıkların Eğitim Yönetimi ve Denetimi Alanındaki Faaliyetlerinin Yasal Belgeler Eşliğinde Analizi. Celal Bayar Üniversitesi Sosyal Bilimler Dergisi, 12(4), 1-18.

Turan, F. (2016). Okul Öncesi Eğitim Kurumlarında Eğitim Öğretim Faaliyetlerinin Denetimi, International Journal of Eurasia Social Sciences, 7(23), 94-119.

Thakral, S. (2015). The Historical Context Of Modern Concept Of Supervision. Journal of Emerging Trends in Educational Research and Policy Studies, 6(1), 79-88.

Yıldırım, A., Şimşek, H. (2013). Sosyal bilimlerde nitel araştırma yöntemleri. Ankara: Seçkin Yayıncılık.

Yılmaz, K. (2009). Supervision Duty Of School Principals. Inönü University Journal of the Faculty of Education, 10(1), 19-35. 


\title{
The Examination of the Supervisory Guideline of Private Student Study Centers Based on Legal Documents and Literature
}

\author{
Dr. Aysun AKÇAY GÜNGÖR \\ Ministry of Education-Turkey \\ aakcay86@gmail.com
}

\begin{abstract}
The aim of this study is to examine the Supervisory Guideline of Private Student Study Centers Based on Legal Documents and Literature. Document review method, one of the qualitative research methods, was used in the research. Document review comprises the analysis of written materials containing information about the phenomenon or facts to be investigated. The data obtained were subjected to content analysis. According to the research findings, it has been observed that the supervisory guideline is generally consistent with legal documents. On the other hand, it has been determined that there are inconsistencies such as referring to incomplete, excessive or erroneous to the legal foundation, referring to obsolete articles, the presence legal loopholes and the inability to access the legal basis from the internet in the guide. When the guide is analyzed on the basis of the literature, it was seen that the guideline was mostly consistent with the literature, but it had not been referenced to the literature when the guideline was constituted, and the findings obtained from the literature had not been involved in the guide. It may be suggested that the supervisory guideline of the private student study center should be updated with the support of academicians and lawyers from the field, based on new legal documents and literature, and that all legal documents included in the guideline should be collected in an accessible platform.
\end{abstract}

Keywords: Supervisory Guideline, Private Students, Study Centers, Legal Documents.

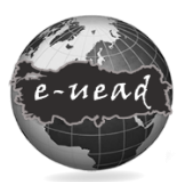

E-International Journal of Educational Research, Vol: 11, No: 3, 2020, pp.90-109

DOI: 10.19160/ijer.820632

Received: 03.11.2020 Accepted: 06.12.2020

\section{Suggested Citation:}

Güngör, A., A. (2020). The Examination of the Supervisory Guideline of Private Student Study Centers Based on Legal Documents and Literature, E-International Journal of Educational Research, Vol: 11, No: 3, 2020, pp. 90-109, DOI: 10.19160/ijer.820632 


\section{EXTENDED ABSTRACT}

Problem: The aim of this study is to examine the Supervisory Guideline of Private Student Study Centers Based on Legal Documents and Literature. Private education institutions, including special student study centers, which are examined within the scope of the research, are inspected by the inspectors of Ministry Education / inspectors of Ministry Deputy Education or the departmental manager appointed by the provincial directorate of national education and other persons with authority to inspect. In the supervisions of these institutions, modules and other electronic tools and equipment can also be used that are prepared by the Ministry. (Regulation on Private Education Institutions, Article 67) There are Guidance and Supervisory Guides prepared by the department of inspection board for the inspectors to benefit from while performing their supervision duties. These guidance aims to lead Ministry personnel, schools and institutions affiliated to the Ministry, private education institutions, real and legal persons and voluntary organizations in the implementations of the issues concerning the Ministry; to carry out the control and supervision of services in cooperation with the relevant units; to convey the results to the relevant units and persons in report form by analyzing the process and its results according to the legislation, determined goals and objectives, performance criteria and quality standards; to increase the quality of education; to provide unity of implementation and standardization among the Presidencies of Education Inspectors (MEB, 2016). This research was conducted in order to determine how consistent the inspection guide of private student study centers with legal documents and literature.

Method: Document review method, one of the qualitative research methods, was used in the research. Document review comprises the analysis of written materials containing information about the phenomenon or facts to be investigated. As with other research methods, the method of document analysis requires the analysis and interpretation of data in order to make sense, gain understanding and develop empirical knowledge. The data obtained were subjected to content analysis. The data subjected to content analysis are divided into themes, categories and codes. It was reached to 2 themes, 4 categories and 10 codes within the scope of the research. The codes reached are explained with the expressions involved in the guide.

Findings: According to the research findings, it has been observed that the supervisory guideline is generally consistent with legal documents. On the other hand, it has been determined that there are inconsistencies such as referring to incomplete, excessive or erroneous to the legal foundation, referring to obsolete articles, the presence legal loopholes and the inability to access the legal basis from the internet in the guide. The main reason of these inconsistencies is that the supervisory guideline prepared contains only the period in which it was prepared and it cannot keep up with the legal changes and developments. When the guide is analyzed on the basis of the literature, it was seen that the guideline was mostly consistent with the literature, but it had not been referenced to the literature when the guideline was constituted, and the findings obtained from the literature had not been involved in the guide.

Suggestions: In this part of the study, it is included that the results had been induced from the findings of themes, categories and codes obtained from analysis and the suggestions that can be presented to the researchers and practitioners based on these 
results. When the guidance and supervision guide of the private student study center was examined, it was seen that the guide was generally consistent with the legal documents. Although it is an expected result that this guide prepared by the Directorate for Guidance and Inspection of the Ministry of National Education is to be consistent with legal documents, in order to continue this consistency, an online platform can be established to be immediately informed from the current legal developments of the inspectors who prepare and practice the guide. A study that also includes education inspectors which is about continuity of prepared supervision guidelines with legal documents and and what measures can be taken to keep it up to date at all times, to what extent the current inspection guide is used by the inspectors may be advised to researchers. Many points that are inconsistent with legal documents in the superivision guide that was inspected are also identified. The main reason of these inconsistencies is that the supervisory guideline contains only the period in which it was prepared and cannot keep up with the legal changes and developments. It can be suggested to people who prepare the guideline, to follow the change and up-todate of the legal documents contained in the guide and to update the guide as new laws are enacted. It may be proposed to publish the annulled articles or the legal documents that have been abolished on the official website of the Department of Inspection Board immediately. Moreover, it may be suggested to researchers to do research which is about how to make the supervision guideline used by inspectors more functional, clear, useful and accessible and how to increase the quality and quantity of the guide in all kinds of educational institutions in the modern age. It can be said that the supervision guide is generally consistent with the literature; especially many definitions in the guideline are taken from the literature. In order to continue this consistency, it can be proposed that the people who prepare the guideline should be selected from people who are able to access the developments and new scientific information in the literature and to interpret the information they have reached. In addition, before the supervision guides have been updated, activities such as conferences, panels, symposiums and workshops with the participation of academicians from the field can be held. It can be proposed to research the necessity of how and by whom should a good supervision guide be written and if available comparison with supervisions in different countries by researchers. It was observed that the inspected supervision guide was inconsistent with the literature at some points. Many definitions and terms from the literature are used in the guide without reference. This situation overshadows the scientificity of the guide. 